\title{
Stress and Spirituality
}

\section{Journal of Stroke Research (JSR)}

\section{Dr B V Pattabhiram* and Dr Balaji Deekshitulu P V**}

${ }^{*}$ Director Prasanthi Guidance \& Counselling Centre, Hyderabad

**Psychologist \& Alternative Medicine (Homeopathy) Practitioner, Sri Balaji Clinic, Tirupati, A.P, India.

\section{ABSTRACT}

In this review article the author argues that complete presentation of various Spiritual methods can reduce the stress and relat*Correspondence to Author: ed mental and physical illnesses like Stress anxiety, depression Dr Balaji Deekshitulu P V etc.. Life is neither Possible to overcome safely. Spiritual methods like Prayer, Meditation, Mantra and some epic methods are increasing in Physical and mental health and reducing stress is an important stimulus of human growth and creativity as well an inevitable part of life.

How to cite this article:

B V Pattabhiram and Balaji Deek-

\section{Keywords:}

Stress, Spirituality, Prayer, Meditation, Mantra. shitulu P V. Stress and Spirituality. Journal of Stroke Research, 2016,1(1): 0025-0029.

\section{eSciencePublisher}

eSciPub LLC, Houston, TX USA.

Website: http://escipub.com/ 


\section{Introduction}

Mentally high pressure or tension is called stress its can effect total health - physical, mental and emotional in human body. Not all stress is bad. A certain amount of stress can help you to perform at your best.

Stress within your comfort zone can help you perform under pressure, motivate you to do your best, even keep you safe when danger looms. But when stress becomes overwhelming, it can damage your mood and relationships, and lead to a host of serious mental and physical health problems. The trouble is that modern life is so full of frustrations, deadlines, and demands that many of us don't even realize how stressed we are. Whatever your job, by recognizing the symptoms and causes of stress, you can take the first steps to reducing its harmful effects and improving your quality of life.

Two powerful body systems cope with stress. The nervous system controls the rapid body changes, while the endocrine system regulates the longer-term patterns of stress response by releasing hormones into the blood. The adrenal activates the sympathetic nervous system, reducing the normalizing effects of body function. This increases the metabolic rate, heart rate, circulation and blood pressure. In addition, effectiveness of the digestive system is diminished and disturbances in sleep patterns become common.

\section{Causes of stress}

Interchangeably used with the word anxiety, stress relates mutually to social and psychological environment. Major situations like divorce, marriage, retirement, death in the family, pre-natal conditions, a job loss and other emotional upheavals as well as minor hassles like waiting in line for hours, getting struck in a traffic jam, misplacing or losing something, disputes, even daily household chores and competitive examinations in fact any unsettling human experience can sometimes become stressful and play havoc with a person's health.

What are the warning signals? Are you mov- ing towards a stress burnout? If you have been experiencing the symptoms listed below, over extended periods of time, it's time acted - now!

- Can't cope, can't concentrate, Feel hopeless, helpless, depressed.

- Always tired

- Often irritable and angry. Can't control your temper

- Eat too much or too little. Eat too many fats, too much salt and sugar

- Have trouble sleeping. Don't get enough sleep, or sleep too much and still feel tired

- Smoking in excess. More than normal intake of alcohol, caffeine or drugs

- Have frequent headaches, backaches, and stomachaches

- Cut back on exercises

- Family tensions run higher than usual. You and your spouse fight more often

- Not interested in sex.

- Always sick lately. Get cough and colds and other viral infections more often than you used to

- Allergies and skin rashes

- Disinterested in life, in general

\section{Spirituality}

Spirituality means feel it soul, no differences of heart and color, cast it support love and god helps to give our lives context. It's not necessarily connected to a specific belief system or even religious worship. Instead, it arises from your connection with yourself and with others, the development of your personal value system and your search for meaning in life. For many, spirituality takes the form of Indian religious observance, prayer, meditation, mantra or a belief in a higher power. For others, it can be found in nature, music, art etc... they are ...

The Sacrificial Fire: Indian religious worship fire as a benevolent element. From time immemorial the sacrificial fire has been an important item of 
Indian culture.

Deepam or Lamp: The India worship FLAME or JYOTI or DEEPAM, as being the purest of the pure because it consumes all impurities but yet remains pure by itself. It is lighted in every Hindu household and temple in India. The cotton tape keeps sucking the ghee to yield a cool bright light, a flame. In nature the flame is considered to be the source of infinite energy of positive currents.

Tree worship: Trees are considered to be friends of man as they provide him shelter, food, fuel, and oxygen for good living. In the Rigveda and the Atharveda are deified, as "Vriksha Devta" which are considered to be holy and the people ought to worship them. The Pipal, Banyan, Goolar, Amla, Vilva, Sandal, Neem, Mango, and Babool are the trees that are worshipped in India.

Tulsi worship: Tulsi is planted, the place becomes, the place containing tulsi plant becomes pollution free. The oil of the leaves is capable of destroying bacteria and insects.

Betel Leaf (Paan): During worship or rituals, the use of betel leaf is considered as a noble trait and on all auspicious celebrations; betel leaf has become a symbolic item denoting freshness and prosperity. The Skanda Purana says that the Betel Leaf was obtained during the ocean- churning by the Gods. The use of Betel Leaf in India is mentioned in the great epics, The Ramayana and the Mahabharatha as well as in Buddhist and Jain literatures. Paan has rich herbal properties.

Coconut (Nariyel) in rituals: India, for success and prosperity on all occasions, the beginning is done with the breaking of a sanctified coconut.

Lotus Flower: Lotus is a very important symbol of Indian cultural heritage. In the Yogasastra, the six Chakras are depicted with the Lotus as the base. According to the Mahayana sect of Buddhism, all the souls originate from the Lotus.

Chanting AUM: According to the Hindu Yogis in India, inhaling air generates $\mathrm{SH}-\mathrm{Sh}$ sound while exhaling is associated with $\mathrm{HM}-\mathrm{HM}$ and enunciated that SOHAM is the keynote of life. Later they discovered that sound $O$ was guttural and sound AM touched palate and so told that AUM encompassed man's total existence. The Aum sound is vibrating throughout the cosmos and it has three manifestations; those of creations, preservations and destruction. Every time a person utters any letter or word, he puts into operation any of these three virtues of AUM. This invisible power flows through the human body and controls its actions when uttered properly with reverence and concentration.

Tilak or Dot or Bindi: A dot or point is the abode of Shiva and Shakthi. A deep study of human anatomy reveals that the forehead is the best place for applying Tilak. Rishis declared that the junction of the nose-root and the meeting point of the eyebrows is the most sensitive part of the body. The Agya- chakra, or Wheel of wisdom, is located here and so is a vulnerable spot, which must be kept, warm and protected.

Swastik: The sides of the Swastik arms must remain on the right side, moving or stationary for positive vibrations and benevolent results.

Malas: It is a common sight in India, to see saints and rishis wearing small ball-like seeds in a string around their neck. Its aromatic property helps a devotee to get into deep meditation easily. Rudraksha, lotus, Tulasi, Spatica, Chandan, Haldi etc... seeds are not supposed to be rubbed often because then they lose their charm properties. It should be worn on the neck, threaded by gold, silver or woolen threads, so that it remains in gentle touch with the body, which increases the peace and body's immunity.

Ringing of bells: Bells the metallic sounds were also found to attack bacteria and germs through scientific research.

\section{Discussion}

Review of literature supported by Winnie WingYi Chau(2006) suggest that spirituality and church involvement could be used as a coping strategy in the face of acculturative stress among Chinese immigrant college students(1). Inez Tuck et al.(2006)significant that the spiritual well-being proved effective in reducing stress in this healthy adult(2). Delgado C (2007) indicat- 
ed that the psychosocial factors are important in patients' cognitive interpretations of illness. Sense of coherence (SOC) and spirituality may buffer stress in the context of chronic illness (3). Shiv Gautam and Nikhil Jain(2010)studied that the the cultural factors and the belief system on psychopathology (4). Uma Devi(2011)suggested that the stress coping strategies identified by this study includes stress management programs, physical activities planned in job design, life style modification programs, finding triggers and stressors, supportive organization culture, stress counselling programs, and spiritual programs (5). Harold G and Koenig (2012)explain that the religion/spirituality positive outcomes include well-being, happiness, hope, optimism, and gratefulness, and negative outcomes involve depression, suicide, anxiety, psychosis, substance abuse, delinquency/crime, marital instability, and personality traits (positive and negative) (6). Reutter Kirby(2012) confirmed the role of both religiosity and spirituality as effective coping resources. Based on these results, religious and spiritual coping should be acknowledged by mental health professionals (7). Srivastava and Archana Sharma (2014) study that the rich Hindu literature has since years contained methods and techniques that will help mankind to face the pressures and maintain a healthy mind, body and soul (8), Aki Yazawa et al(2014) indicated that the psychology stress among local residents was linked to the lifestyle with less stress (9). Deekshitulu(2014)reviewed that the fallow who ever in Vedic life style is a best remedy for stress and physical and mental health (10). Debnam K et al. (2016) reported that the increasing students' adaptive spirituality coping when confronted with school-related stressors (11). Delaram Badiee(2016)studed that the spirituality in predicting coping style and relationship with the spiritual dimension, it can be created with such capacities in educational situations, coping styles in students promoted (12). Masoumeh masoum et al.(2016)suggested that the increasing spiritual health is decreasing their job stress (13). Nandeesh Y et al.(2016)Yoga practice can lead to a healthy mental health, in terms of reduced depression, anxiety and stress. Yoga practice can lead to increase in Spiritual experience of the practitioners (14).

\section{Conclusion}

Spiritual Methods are relaxation techniques that involve mostly the mind, which in turn affects the physical body as well. These techniques can be used as a stress reducer. In stilling your mind and body, you can forget for a short period the many trials of the day. Studies have shown that Spiritual methods can have beneficial effects on the health of the body as well as positive results in stress reduction levels. There are several ways to Spirituality. Can fallow Spiritual methods quietly alone or within a group can occur during times of activity or at times you deem relaxing such as reading or even washing the dishes. Originally done to commune with oneself spiritually and for other religious reasons, Spirituality methods have become an important tool in todays stressed out society.

\section{REFERENCES}

1. WinnieWing-YiChau(2006) The relationship between acculturative stress and spiritualty among chinese immigrant college students in the united states.University of California, Los Angeles

2. Inez Tuck, Renee Alleyne and Wantana Thinganjana (2006) Spirituality and Stress Management in Healthy Adults, JHS, Vol 24, Issue 4.

3. Delgado C (2007) Sense of coherence, spirituality, stress and quality of life in chronic illness, J Nurs Scholarsh;39(3):229-34.

4. Shiv Gautam and Nikhil Jain(2010) Indian culture and psychiatry, Indian J Psychiatry; 52(Suppl1): S309-S313.

5. Uma Devi(2011) A Study on Stress Management and Coping Strategies With Reference to IT Companies, Journal of Information Technology and Economic Development 2(2), 30-48.

6. Harold G and Koenig (2012) Religion, Spirituality, and Health, SRN Psychiatry, Volume 2012, Article ID 278730, 33 pages.

7. Reutter, Kirby, the Effects of Spirituality and Religiosity upon Stress, Anxiety, and Depression: Mediation, Moderation, or Moderated Mediation?, Northcentral University, 2012, 98.

8. Sachin Kumar Srivastava and archana sharma(2014) Impact of Stress on Front Line/ Business Management Executives and IT's Solution, Social Science Electronic Publishing.

9. Aki Yazawa, Yosuke Inoue, Dandan L, Jianwei Du ,Yuming Jin ,Yan Chen ,Masaru Nishitani ,Chiho 
Watanabe and Masahiro Umezaki (2014) Impact of lifestyle changes on stress in a modernizing rural population in Hainan Island, China, American Journal of Human BiologyVolume 26, Issue 1, pages 36-42.

10. Deekshitulu(2014)Vedic life style in stress control, Innovare Journal of Health Sciences, Vol 2, Issue 2, 2014,1-32.

11. Debnam K, Milam AJ, Furr-Holden CD, Bradshaw (2016) The Role of Stress and Spirituality in Adolescent Substance Use, U.S. National Library of Medicine, 11;51(6):733-41.

12. Delaram Badiee(2016) The Relationship of Spirituality with the Styles of Coping with Stress among College Students, The Caspian Sea Journal, Volume 10, Issue 1,302-305.

13. Masoumeh mamsoum, Rahim,tahmasebi,meh rdad,jalali,farideh jafari(2016)The studyof the relationship between job stress and spiritual health of nurses working in intensive care ward at Bushehr hospitals, Nvj,3(8);37-47.

14. Nandeesh Y. D, Deepa Kulkarni, Shanmukh V. Kamble(2016) Depression, Anxiety, Stress and Spirituality in Yoga Practitioners, The International Journal of Indian Psychology, Volume 3, Issue 3, No.9. 